УЧАСТЬ У ФОРМАХ ЛІКАРНЯНОЇ АНІМАЦІЇ ЯК ЗАСІБ ФОРМУВАННЯ
ГУМАНІСТИЧНИХ ЦІННОСТЕЙ СТУДЕНТІВ-ВОЛОНТЕРІВ

\title{
PARTICIPATION IN THE FORMS OF HOSPITAL ANIMATION AS A MEANS OF FORMATION OF HUMANISTIC VALUES OF STUDENT VOLUNTEERS
}

\begin{abstract}
У статmі здійснено аналіз поглядів сучасних вітчизняних і закордонних учених стосовно вивчення емоцій, почуттів, сміху, гуманізму та виховання гуманістичних цінностей студентів педагогічних вишів, позанавчальної та анімаційної діяльності, питання волонтерства, зокрема у соціальній роботі. Описано емоційний стан дитини, госпіталізованої на стаціонарне лікування. Така дитина не просто відривається від звичного оточення та життя, а ще й стає об'єктом різноманітних болісних і неприємних маніпулячій і процедур; коло ї спілкування змінюється й обмежується. Перераховано громадські організації, що займаються лікарняною анімацією. Розкрито зміст роботи проекту «Терапія радістю» та перелічено акції, які проводяться згідно з датами соціального календаря на базі лікарень. Висвітлено історію походження перших лікарняних клоунів $і$ їх поширення по всьому світу. Відображено аналіз державної підтримки цієї профресії у різних країнах. Розглянуто діяльність організації «Червоні носи» в Україні та відзначено ї засновників, котрі започаткували лікарняну анімацію. Проаналізовано особливість роботи лікарняних клоунів за умов стаціонарного лікування та показано кінцевий результат досягнення мети, коли дитина охоче йде на контакт і бере участь у медичних маніпуляціях. Доведена важливість проходження навчання у Школі волонтерів і Школі лікарняного клоуна. 3'ясовано зміст навчання студентів-волонтерів перед початком роботи у стачіонарі, що відбувається в різних формах. Зроблено висновок про взаємозв'язок розвитку гуманістичних цінностей студентів під час участі в різноманітних срормах лікарняної анімації в позанавчальній діяльності на волонтерських засадах.

Ключові слова: емоції, лікарняна клоунада, арт-терапія, студенти-волонтери, гуманістичне виховання, благодійні фонди.
\end{abstract}

The article analyzes modern domestic and foreign opinions concerning the study of emotions, feelings, laughter, humanism and education of humanistic values of students of pedagogical universities, extracurricular and animation activities, volunteering, in particular in social work. The emotional state of a child hospitalized for inpatient treatment according to age periodization is described. Note that upon admission to inpatient treatment, the child not only detaches himself from the usual environment and life, but also becomes the object of various painful and unpleasant manipulations and procedures; it is obvious that the circle of her communication is changing and limited. The public organizations engaged in hospital animation are listed. The content of the project Therapy with Joy is revealed and the actions carried out according to the dates of the social calendar on the basis of hospitals are listed. The history of the origin of the first hospital clowns and their spread around the world is covered. An analysis of state support for this profession in different countries. The activity of the organization "Red Noses" in Ukraine is considered and its founders who started hospital animation are noted. The peculiarity of the work of hospital clowns in the conditions of inpatient treatment is analyzed and the final result of achieving the goal is shown, when the child willingly comes into contact and participates in medical manipulations. The importance of training at the Volunteer School and the Hospital Clown School, which take place across the country with invited foreign coaches, has been proven. The content of the training that volunteer students undergo before starting work in the hospital, which takes place in various forms, is clarified. It is concluded that the relationship between the development of humanistic values of students while participating in various forms of hospital animation in extracurricular activities on a volunteer basis.

Key words: emotions, hospital clowning, art therapy, student volunteers, humanities education, charitable foundations.
Постановка проблеми у загальному вигляді. Сьогодні в Україні важлива роль відводиться громадському руху, оскільки державні організації не повною мірою охоплюють запити суспільства. Дедалі частіше ми спостерігаємо прояв нових фрорм соціально-культурного досвіду, які найчастіше приходять до нас із європейськими традиціями та новаціями. Одним із таких проектів $\epsilon$ волонтерський рух «Терапія радістю», в рамках якого здійснюється відвідування медичних закладів із різноманітними заходами для рекреації та покращення лікування дітей, що тривалий час перебувають у стаціонарі.

Здоров'я, за визначенням Всесвітньої організації охорони здоров'я, є станом повного фрізичного, психічного та соціального благополуччя, а не лише відсутністю хвороби або недуги [2, с. 96]. Важлива роль у процесі одужання та якісного життя особистості належить позитивним емоціям і сміху. Сміх - вираз емоційного стану людини, пов'язаний із переживанням неоднозначної, смішної ситуації, який супроводжується рядом фрізіологічних реакцій організму [10].

Тривале перебування у лікарні зумовлює появу дезадаптативних психоемоційних станів як у дітей, так і у їхніх батьків. Власне госпіталізація часто призводить до підвищення тривоги, психоемоційної напруги, дратівливості, інколи до зниження самооцінки та сорому через те, що захворів і не можеш займатися улюбленою справою чи навчанням. Подеколи, у віці до трьох років, перенесене дитиною захворювання може спричинити пору- 
шення ії фрізичного, особистісного чи інтелектуального розвитку. Також варто відзначити, що така дитина не просто відривається від звичного оточення та життя, а ще й стає об'єктом різноманітних болісних і неприємних маніпуляцій і процедур; коло їі спілкування змінюється й обмежується. У такій ситуації стресостійкі резерви хворої дитини зменшуються, що погано відображається як на ії здоров'ї, самопочутті, так і на процесі одужання.

Адаптація хворої дитини залежить від віку і типу захворювання за умов стаціонарного лікування. На думку психологів Л. Балим, О. Москаленко, немовля у віці до 3-4 місяців слабо реагує на зміну оточення, якщо ритм і якість годування, а також спосіб догляду за ним не змінюється. У віці від 4 місяців до 2-3 років розширюється коло уявлень дитини про світ, тому вона шукає навколо знайомі предмети. Зміна оточення для дитини означає зміну звичних контактів і подій, тож у цьому віці найбільш виражені труднощі адаптації. Із 3 до 6 років дитина вже краще пристосовується до змін внаслідок великої гнучкості своєї нервової системи та зміцнення організму. Проте медичні маніпуляції можуть викликати тривогу і навіть депресію. Із 7 років у дітей, які перебувають на стаціонарному лікуванні, на перший план виступають соціальні проблеми - відрив від друзів, неможливість продовження шкільного навчання тощо $[1$, с. 5].

Тому для полегшення адаптації, перебування та швидшого одужання дитини у лікарні рекомендується участь у різноманітних заходах, що проводять громадські організації. Найбільш поширеними формами лікарняної анімації $€$ напрям «Терапія радістю», який включає в себе проект «Лікарняний клоун», арт-терапевтичні проекти (малювання, виготовлення майстерок, терапевтичні казки, прослуховування музики тощо), а також безліч акцій, що проводяться згідно 3 датами соціального календаря («Миколай дітям у лікарнях» - 19 грудня, «День онкохворої дитини»15 грудня, «День захисту дітей» - 1 червня, «День донора» - 14 червня і т. д.).

Аналіз останніх досліджень і публікацій. Вивченням питання емоцій займалися такі провідні науковці, як П. Анохін, Б. Базима, Ч. Дарвін, У. Джеймс, Г. Костюк, К. Ленге, А. Петровський, С. Рубінштейн, П. Симонов, 3. Фройд. Згідно 3 уявленням Г. Бреслава, Л. Виговського, В. Вілюнас, Л. Ізарда, А. Леонтєва та ін., почуття, виступаючи як регулятори дії, виконують головну пристосувальну фрункцію, організовуючи взаємодію суб'єкта із зовнішньою сферою, забезпечуючи фрункціональні форми його життєдіяльності [3, с. 4]. Про вплив сміху на організм людини писали такі відомі лікарі, фрілософи та психологи, як Авіцена, Т. Ахола, Р. Бартон, І. Кант, Р. Мартін, Ф. Ніцше, Піфрагор, Ф. Рабле, Г. Сковорода, Сократ, Й. Шульц та ін. Вони стверджують, що позитивні емоції $€$ запорукою здорового духу й тіла, забезпечують успішну соціалізацію особистості, сприяють соціальній комунікації з індивідами. «Як не можна приступити до лікування ока, не думаючи про голову, чи лікувати голову, не думаючи про весь організм, так не можна лікувати тіло, не лікуючи душу», стверджував Сократ.

Щодо проблеми гуманізму, виховання гуманістичних цінностей у студентів педагогічних вишів, то вони відображені у роботах вітчизняних і зарубіжних вчених Б. Ананьєва, В. Андрущенко, Т. Антоненко, Ш. Амонашвілі, О. Базалука, М. Бердяєва, І. Беха, Є. Бондаревської, А. Бойко, М. Боришевського, Л. Буєвої, Л. Губерського, О. Дробницького, Є. Зеленова, В. Киричок, В. Кременя, С. Кримського, О. Лазурського, Д. Леонтєва, О. Лосєва, С. Максименка, М. Мамардашвілі, Н. Миропольської, А. Печчеї, Е. Помиткіна, М. Роганової, В. Роменця, Т. Титаренко, А. Швейцера. Варто відзначити дослідження сучасних учених про гуманізм, гуманістичне ставлення до особистості та власне педагогічний аспект (праці К. Гавриловець, О. Лямової, Н. Слободяник).

Важливість позанавчальної діяльності для студентів як провідної діяльності у вільний час вивчали С. Савченко, С. Шашенко та ін., підготовку фрахівців до організації анімаційної діяльності та дозвілля розглядали Л. Волик, В. Кірсанов, Т. Лесіна, С. Пащенко, В. Плотникова, І. Шульга.

Людські ресурси волонтерського руху розглядали Р. Вайнола, А. Капська, Н. Комарова та ін. Питаннями волонтерства в соціальній роботі займалися Ю. Гапон, І. Звєрєва, Г. Лактіонова л. Романенкова та ін.

Виділення не вирішених раніше частин загальної проблеми. Можна зробити висновок, що питання формування гуманістичних цінностей студентів-волонтерів за умов стаціонару під час занять різноманітними видами лікарняної анімації досі не досліджено.

Мета статті - показати взаємозв'язок розвитку гуманістичних цінностей студентів під час участі у різноманітних фрормах лікарняної анімації, у позанавчальній діяльності на волонтерських засадах.

Виклад основного матеріалу. Як уже згадували раніше, госпіталізація на стаціонарне лікування є травматичним досвідом для дитини і їі близьких. Л. Хофрф аналізує це середовище як певну субкультуру. Лікарі, медсестри та інший персонал знають і дотримуються правил, певних ритуалів перебування у лікарняному закладі, що запобігає хаосу і допомагає вправно виконувати роботу. Дитина, особливо якщо вона вперше госпіталізована, може відчувати певний культурний шок, стан фрізичного, емоційного дискомфорту, дезорієнтації, спричинені потраплянням в нове та незнайоме місце [8, с. 340-341]. Медичний персонал зайнятий лікуванням (і за браком часу, 
відсутності навичок підтримки) часто забуває, що госпіталізація є великим стресом для дитини та її батьків. Без підтримки в незнайомому середовищі здатність пацієнта успішно справлятися з хворобою та стресом значно знижується.

У своєму дослідженні Л. Картрайт «Надзвичайні ситуації виживання» виявив, що травмуючий ефект перебування в лікарні, особливо тривалого, для дітей пов'язаний із великою кількістю болючих процедур і маніпуляцій. Наслідками такого шоку можуть бути: зниження рівня адаптації до оточення, послаблена опірність до інфекції, замкнутість, порушення харчової поведінки та ін. [6, с. 35-49].

Тому у більшості обласних і великих лікарень нашої країни (у таких містах, як Київ, Львів, ІваноФранківськ, Рівне, Харків, Запоріжжя, Дніпро, Вінниця, Кропивницький та ін.) діють програми, спрямовані на покращення емоційного стану дитини та їі батьків. Такі програми реалізують громадські організації, серед яких Львів БФ «Запорука», БФ «Крила надії», Івано-Франківськ БФ «Янголи поруч», Рівне ГО «Червоні носи».

Зрозуміло, що персонал благодійних фрондів і громадських організацій невеликий, тому вони потребують залучення волонтерів до практичної діяльності, а самі займаються організаційними моментами (залученням спонсорів / інвестицій, навчанням / наставництвом і т. д.). Здебільшого це студенти вишів. $€$ проекти, що діють на постійній основі (терапія радістю, арттерапія, ігротерапія, читай клуб, кіноклуб), а є безліч програм та акцій, присвячених соціальному календарю.

Наймаштабнішою сьогодні з інноваційних технологій психосоціальної роботи, спрямованою на покращення адаптації та реабілітацію дитини у стаціонарному просторі, є лікарняна клоунада, a саме напрям «Терапія радістю». С. Міллер і Т. Сиротина провели дослідження серед лікарняних клоунів. Вони з'ясували, що основна мета їхньої діяльності - допомога в адаптації за умов лікарняного середовища, сприяння у виплеску емоцій (як позитивних, так і негативних), відволікання дітей і батьків від стаціонарних буднів, створення безпечного та ресурсного середовища для дитини у лікарні [5, с. 17].

Історія розвитку лікарняної клоунади в світі нараховує більше 40 років, в Україні - вже понад 10 років. Перші волонтери з'явилися в Рівному, потім у Києві, Черкасах, Харкові, Львові і т. д.

Витоки лікарняної клоунади можна прирівняти до виникнення та розвитку клоунади загалом. У Стародавній Греції коміки були без волосся та мали здаватися повними, щоб бути більшими, ніж звичайна людина. Вони виступали як другорядні герої в пантомімах і комедіях, пародіюючи головних, більш серйозних персонажів. У Стародавньому Римі клоун носив гостру високу шапку та різнокольоровий одяг. Він був об'єктом жартів, образ і навіть побоїв. Клоун як самостійний персонаж з'являється у пізньому Середньовіччі. У XVI ст. в імпровізованих комедіях були народжені багато типових сучасних клоунів, у т. ч. Арлекін. Він виник як комічний слуга, лакей, але незабаром став акробатом, брехуном, що мав чорно-білу маску доміно і палицю, якою часто бив своїх жертв. Ще одним персонажем, що дійшов до сучасності $€$ П'єро, який також був об'єктом для висміювання та витівок [7].

Молодий лікар, котрий у 1970 р стає першим лікарняним клоуном, $€$ «Патч» Адамс або Хантер Доерті Адамс (справжнє ім'я). Він сприймав медицину як єдину професію: турбота і любов до пацієнта разом із його лікуванням. Хантер Адамс обрав професію сімейного терапевта і вирішив лікувати бідних. Під час навчання в медичному коледжі у Вірджинії (США) студент усвідомив, що тільки любов і гумор можуть протистояти агресії та болю. Працюючи в лікарні, він поєднував свою медичну практику із клоунадою. За біографрією «Патча» Адамса у 1998 р. в Голівуді зняли фрільм «Цілитель Адамс», головну роль у якому зіграв Робін Вільямс. Його приклад і позитивний досвід швидко став відомим у багатьох країнах, де й почали з'являтися послідовники Патча Адамса, котрі щоразу вдосконалювали та розвивали свої навички та майстерність [4].

У 1987 р у м. Нью-Йорку було відкрито підрозділ опіки лікарняних клоунів «Велике яблуко», який став новим етапом у розвитку цієї професії. Ії̈ засновником став М. Крістенсен. Ця програма діє і сьогодні, основа увага зосереджена на дитячих лікарнях Нью-Йорка, проте лікарняні клоуни працюють і в інших стаціонарах США. М. Крістенс і його колеги із проекту «Велике Яблуко» були запрошені виступити в одній із дитячих лікарень міста. Вони розіграли двадцятихвилинну сценку, де пародіювали звичайне лікарняне життя. Аудиторія, що в більшості складалася 3 дітей і їхніх батьків, заходилася від сміху й радості; лікарі ж помітили позитивну динаміку у лікуванні. Для М. Крістенса і його колег цей виступ став поштовхом до створення професії лікарняного клоуна [9].

Діяльність цих лікарняних клоунів була спрямована на задоволення психосоціальних потреб госпіталізованих дітей і їхніх батьків, а саме: зниження стресу, пов'язаного з перебуванням у лікарні та власне лікарняними маніпуляціями. Проект «Велике Яблуко» поширювався і на дорослі відділення. Вони й надалі пародіювали щоденну рутинну роботу лікарів, відволікали від медичних процедур, допомагали зрозуміти їхній зміст і те, як вони будуть проведені. Атмосорера сміху, гри, забави допомагали дітям і дорослим забувати про свою хворобу і біль хоча б на певний час.

Надалі лікарняні клоуни почали з'являтися в медичних закладах Великої Британії. У країнах 
Західної Європи та США програма «лікарняний клоун» $€$ складовою частиною оздоровчих програм великих лікарень упродовж 25 років. У Німеччині створена асоціація лікарів-клоунів. У лікарнях Австрії та Нідерландів у штатному розкладі передбачені посадові ставки «лікарняних клоунів». у Чехії фрункціонує громадська організація «Лікарняний клоун». У Польщі «Доктор клоун» існує вже понад 15 років, і за цей час створено 23 осередки по всій країні. Такі самі організації діють у Канаді, Бразилії, Франції, Росії, Казахстані, Ізраїлі, Угорщині та ін. Хоч вони і називають себе по-різному (Лікар радість, Весела медицина, Смішні носи, Клоуни для здоров'я), проте виконують оду й ту саму місію. Одним із найбільш значимих спонсорів лікарняних клоунів є Фонд Феодора, який підтримує клоунів у 82 країнах Європи, Азії та Африки.

В Україні лікарняні клоуни як регулярний волонтерський рух з'явилися 10 років тому в Рівному. Два друга Тарас Обоїст і Артем Алєксєєв почали приходити до пацієнтів обласної дитячої лікарні. Вони пройшли московську школу підготовки та заснували свою, запрошують клоунів 3 інших країн для проведення тренінгів, вдосконалення майстерності. Тепер клоуни-волонтери $€$ в інших великих містах, рівняни навчають нових клоунів по Україні, але й досі залишаються одними з небагатьох, хто ходить до дітей мінімум раз на тиждень.

Т. Обоїст стверджує, що лікарняними клоунами можуть бути як професійні актори, аніматори, так і люди будь-яких професій і студенти, котрі пройшли спеціальні курси. Найважливішим у цій роботі є симбіоз актора-клоуна з пацієнтом у безпосередньому спілкуванні. Одяг волонтери використовують різний: можуть бути розмальовані лікарні халати або ж костюми клоунів.

Перед приходом до хворої дитини лікар-клоун завжди консультується 3 медичним персоналом відділу, дізнається імена пацієнтів, характеристики хвороби, отримує інорормацію про палати 3 важкими хворими. Лікарняний клоун завжди питає дозволу про візит. Якщо хвора дитина погано почувається і нікого не хоче бачити, то вона має право сказати «ні». Це дає можливість дитині самій приймати рішення і відчувати власну важливість, адже в лікарні ніхто не питає їі, які робити процедури.

Важливо відзначити дві особливості їхньої роботи: по-перше, клоуни працюють у парі, де $є$ розподіл ролей - головний і відомий. Завдання головного клоуна - бути серйозним, тоді як інший «пустує». Робота в парі допомагає залучити до комунікації пацієнтів, із самого початку створює простір, наповнений гумором і сміхом. По-друге, лікарняні клоуни мають не лише працювати за складеним сценарієм, а й імпровізувати. Під час комунікації клоуни залучають пацієнта до своєї гри або пристосовуються до тої, яку пропонує сама дитина. Так, наприклад, лікарняний клоун може зробити «укольчик» подушці, побитися кульковими мечами, нагодувати ляльку й таке ін. Якщо дитина у руках клоуна побачить замість градусника чарівний предмет, у якому живе ртутний гномик, - то мета досягнута. У такому жанрі ніби «віддзеркалюється» лікарняна дійсність, яка оточує дитину, і страшний шприц вже не несе біль, а стає казковим фонтаном і занурює пацієнта в інший паралельний світ. Як говорив головний герой фрільму «Цілитель Адамс»: «Намагайся побачити те, що не бачать інші; те, що інші відмовляються бачити через страх. Сприймай весь світ, кожен день заново».

Діти із задоволенням відвідують заняття із клоунами та волонтерами, які щонайменше відбуваються один раз на тиждень.

Як уже згадувалося раніше, на допомогу лікарняним клоунам приходять студенти, найчастіше педагогічних вишів і соціальних спеціальностей. Це, власне, волонтери, яким найбільше притаманні гуманістичні цінності та які прагнуть розвивати їх надалі. Для забезпечення ефективної роботи вони проходять навчання у Школі волонтера та безпосередньо у Школі лікарняного клоуна, яка проводиться два рази на рік у різних містах країни. Заняття у формі тренінгів, дискусій спрямовані на підвищення рівня знань молодих людей про психологію хворої дитини, техніки зниження бар'єрів міжособистісного спілкування з батьками хворих діток, медичним персоналом, фрормування навичок індивідуальної та групової взаємодії з хворими дітьми залежно від їх віку та нозологічної форми. Також на тренінгах студенти вивчають особливості психоемоційного стану дітей, котрі перебувають на стаціонарному лікуванні; переваги використання арт-терапії, ігротерапії, казок, мульторільмів / фрільмів як засобів зниження тривоги й ефективної взаємодії з дітьми в лікарні.

Навчання студентів у Школі волонтерів, Школі лікарняного клоуна проходять за підтримки БФ «Крила надії», яка займається особливостями організації діяльності у дитячих лікарнях Львова.

Висновки. Для полегшення перебування дитини у лікарні батькам (опікунам) і психологам дуже важливо зберегти в дітей віру у швидке одужання, використовуючи для цього методи тілесноорієнтованої терапії (обійми, дихальні вправи та ін.) та арттерапії (малюнки, терапевтичні казки, іграшки, музику та ін.). Використання батьками терапевтичних казок, де головний герой схожий на дитину, має те саме ім'я, переживає ті самі страхи й успішно долає життєві труднощі, допоможе покращити психоемоційний її стан і показати альтернативну модель поведінки у ситуації, що склалася.

На допомогу батькам і лікарям приходить лікарняна клоунада, котра уособлює соціальний феномен і виступає міжкультурним каналом взаємодії. У цій профресії важлива роль належить волонтер- 
ському руху та громадській позиції, адже стабільної державної підтримки та фрінансування нині немає. Проте лікарняні клоуни виконують важливу соціальну функцію - всіма своїми засобами допомагають зберегти, підтримати, відновити фрізичне, духовне та соціальне здоров'я дитини. Різноманіття їхніх практик дозволяє кожному пацієнту обрати для себе такі, що відповідають його віку, фрізичним потребам, соціальним очікуванням.

Використовуючи якісно свій позанавчальний час, студенти, зокрема педагогічних вишів, беруть участь у різноманітних проектах, у т. ч. «Терапія радістю». Волонтери мають можливість отримати колосальний досвід і навички. Вони проходять навчання та мають наставників / порадників. Студентські волонтерські об'єднання, які є більш стабільними, отримують особливий погляд на життя. Їхня добровільна допомога є безкорисним, гуманним служінням дітям.

\section{БІБЛІОГРАФІЧНИЙ СПИСОК:}

1. Москаленко В.В. Психологія соціального впливу : навчальний посібник. Київ : Центр навчальної літератури, 2007. 448 с.

2. Словник-довідник 3 екології : навчально-методичний посібник / за ред. О.Г. Остапішина. Херсон : ПП Вишемирський В.С., 2013. С. 96-97.
3. Ленский А.Н. Потреби, мотиви, емоції. Психологія емоцій. Тексти / за ред. В.К. Валенасса, Ю.Б. Гіппенрейтер. Москва, 2010. 89 с.

4. Рагожина Е. Патч Адамс. Смех, открывающий души. Новый стиль. 2013. Февраль. № 16. URL: http://www.newstyle-mag.com/personalii/patch-adamssmex-otkryvayushhij-dushi.html.

5. Сиротина Т.В. Больничная клоунада как технология адаптации и реабилитации ребенка в больничном учреждении. Baikal Research Journal. 2015. T. 6. № 6. DOI: 10.17150/2411-6262.2015.6(6).17.

6. Cartwright L. "Emergencies of survival": moral spectatorship and the "New vision of the child" in postwar child psychoanalysis. Journal of Visual Culture. 2004. Vol. 3 (1). P. 35-49.

7. Clown Doctors: the Hum our Foundations : вебсайт. URL: http://www.humourfoundation.com.au/ resources/history-of-clowning.html.

8. Hoff L.A. People in crisis: understanding and helping. San Francisco : Jossey-Bass Publishers, 1995. $477 \mathrm{p}$.

9. Koller D. The Life Threatened Child and the Life Enhancing Clown: Towards a Model of Therapeutic Clowning. Evidence-Bases Complementary and Alternative Medicine. 2007. № 5 (1). DOI: 10.1093/ ecam/nem033//https://www.ncbi.nlm.nih.gov/pmc/ articles/PMC2249744/pdf/nem033.pdf.

10. Сміх Матеріал з Вікіпедії : веб-сайт. URL: https://uk.wikipedia.org/wiki/Смiх. 